\title{
Preliminary Phytochemical Analysis and Invitro Anti-viral Activity of Ethanolic extract of Whole plant of Tinospora cordifolia (Thunb.) Miers against Hepatitis-A Virus
}

\author{
Ramaiah Maddi $^{*}$, Venkata Lakshmi Kandula ${ }^{2}$, Bhagyavathi Vallepu ${ }^{3}$, \\ Hymavathi Navuluri ${ }^{4}$, Harshavardhan Kolluri ${ }^{5}$, Divya Teja Vunnam ${ }^{6}$ \\ ${ }^{1,2,3,4,5,6}$ Department of Pharmacognosy, Hindu college of Pharmacy, Guntur-522002, A.P., India \\ *Corresponding Author: rampharma83@gmail.com, Tel.: +91-8121530528
}

Available online at: www.isroset.org

Received: 23/May/2018, Revised: 04/Jun/2018, Accepted: 19/Jun/2018, Online: 30/Jun/ 2018

\begin{abstract}
Herbal product design refers to the process of developing, standardizing, processing, and validating an herbal product for the market. Hepatitis A is an infectious disease of the liver caused by the hepatitis A virus (HAV). There are no specific medicines to cure infection with hepatitis A. Hence, there is a need for the development of less toxic, more efficacious and cost-effective antiviral agents. The present work highlighted the invitro anti-viral activity of ethanolic extract of whole plant of Tinospora cordifolia (Thunb.) Miers against HAV. Ethanolic extract of the selected plant was prepared by soxhlet apparatus and rotavap. For the antiviral screening against HAV, toxicological effect of selected plant extract was determined through MTT (3-(4,5-dimethylthiazol-2-yl)-2,5-diphenyltetrazolium bromide) cell proliferation assay using Huh-7 cell lines. The standard used is Camptothecin (CPT) at $25 \mu \mathrm{G}$ concentration. Plant extract was tested at $3.125 \mu \mathrm{g} / \mathrm{mL}, 6.25 \mu \mathrm{g} / \mathrm{mL}, 12.5 \mu \mathrm{g} / \mathrm{mL}$, $25 \mu \mathrm{g} / \mathrm{mL}$ and $50 \mu \mathrm{g} / \mathrm{mL}$ concentrations. The cell morphology was observed and recorded under microscope. The results clearly indicated the selected plant extract shows a dose dependent activity and it was maximum at $50 \mu \mathrm{g} / \mathrm{mL}$ concentration where it shows only $56.24 \%$ of virus viability and it was comparable to standard drug where it shows $43.01 \%$ of viability. Phytochemical screening of selected plant extract reveals the presence of different secondary metabolites like alkaloids, flavonoides, tannins, resins, steroids. Presence of these compounds in alone or combination might be responsible for the observed antiviral activity.
\end{abstract}

Keywords - Tinospora cordifolia; whole plant; MTT assay; Huh-7 cell lines; anti-viral

\section{INTRODUCTION}

Over the centuries humans have relied on plants for basic needs. It was estimated in the Bulletin of the World Health Organization (WHO) that around $80 \%$ of the world's population relied on medicinal plants as their primary healthcare source [1]. An herb (also called a botanical) is a plant or plant part used for its scent, flavor, and/or therapeutic properties Herbal product design refers to the process of developing, standardizing, processing, and validating an herbal product for the market [2].

Menispermaceae is a family of flowering plants. Tubocurare, a neuromuscular blocker and active ingredient in curare, is derived from plants of this family. The family contains 68 genera with some 440 species, which are distributed throughout low-lying tropical areas with some species present in temperate and arid regions [3]. Tinospora cordifolia (Thunb.) Miers, (Figure 1) which is known by the common names heart-leaved moonseed, guduchi and giloy, is an herbaceous vine of the family Menispermaceae indigenous to the tropical areas of India, Myanmar and Sri Lanka [4]. It grows throughout tropical India, ascending to an altitude of $300 \mathrm{~m}$. T.cordifolia shows diversified ethno botanical actions. The stem is used in general debility, dyspepsia, fevers and urinary diseases. The bitter principles present in the drug show antiperiodic, antispasmodic, antiinflammatory and antipyretic properties. The plant is used in Ayurvedic rasayanas to improve the immune system and the body's resistance against infections. It is used as an immunomodulator in immunosuppression of obstructive jaundice, hepatic fibrosis, peritonitis and sepsis [5].

A virus is a small infectious agent that replicates only inside the living cells of other organisms. Hepatitis A is an infectious disease of the liver caused by the hepatitis A virus (HAV). There are no specific medicines to cure infection with hepatitis A. Hence, there is a need for the development of less toxic, more efficacious and costeffective antiviral agents. The present work highlighted the invitro anti-viral activity of ethanolic extract of whole plant of Tinospora cordifolia (Thunb.) Miers against HAV through MTT (3-(4,5-dimethylthiazol-2-yl)-2,5-diphenyltetrazolium bromide) cell proliferation assay using Huh-7 cell lines. 


\section{METHODOLOGY}

\section{Plant material}

The plant material T.cordifolia was collected from the local regions of Guntur, Andhra Pradesh (A.P.), India, in August 2017. The plant species was authenticated by Dr. Maddi Ramaiah, Pharmacognosist, Department of Pharmacognosy, Hindu College of Pharmacy, Amaravathi Road, Guntur, A.P., India.

\section{Preparation of crude extract by Maceration}

The dried powdered plant material (whole plant, 1500g) was allowed to contact with solvent ethanol in a closed vessel and then allowed to macerate with occasional shaking for 7 days. Strain the liquid, press the marc; mix the liquids and finally clarifying by filtration. The extract thus obtained was concentrated under vacuum $\left(50^{\circ} \mathrm{C}\right)$ by using Rotary Evaporator (rotavap), dried completely and weighed. The extract thus collected subjected to preliminary phytochemical studies [6-10] and invitro anti-viral assay. The percentage yield was found to be $45.35 \% \mathrm{w} / \mathrm{w}$. The selected plant extracts were prepared with concentrations of $100 \mu \mathrm{g} / \mathrm{ml}$ and syringe filtered using $0.22 \mu \mathrm{M}$ sized syringe filtration units to ensure sterility.

\section{Chemicals, viral strain and cell lines}

Cell culture medium; DMEM- High Glucose (\#AL111, Himedia); Adjustable multichannel pipettes and a pipettor (Benchtop, USA); Fetal Bovine Serum (\#RM10432, Himedia); MTT Reagent (5 mg/ml) (\# 4060 Himedia); DMSO (\#PHR1309, Sigma); Camptothecin (\# C9911, Sigma); D-PBS (\#TL1006, Himedia), 96-well plate for culturing the cells (Corning, USA); T25 flask (\# 12556009, Biolite - Thermo); $50 \mathrm{ml}$ centrifuge tubes (\# 546043 TARSON); $1.5 \mathrm{ml}$ centrifuge tubes (Tarson); $10 \mathrm{ml}$ serological pipettes (Tarson); 10 to 1000 ul tips (Tarson); 96well ELISA plate reader or spectrophotometer capable of measuring the absorbance (ELX-800 Biotek); Inverted microscope (Biolink); $37^{\circ} \mathrm{C}$ incubator with humidified atmosphere of $5 \% \mathrm{CO} 2$ (Healforce, China)

Selected Viral Strain: Hepatitis A Virus (HAV) was provided by Department of Microbiology, Indian Institute of Science, Bengaluru, Karnataka, India.

Selected Cell Line: The Huh-7 (hepato cellular carcinoma) cell lines were compassionately offered by National Centre for Cell Science, Pune, India. Huh-7 cells were cultured in Dulbecco's modified Eagle medium (DMEM) supplemented with $10 \%$ fetal bovine serum, $100 \mathrm{IU} / \mathrm{ml}$ penicillin and 100 $\mu \mathrm{g} / \mathrm{ml}$ streptomycin at $37^{\circ} \mathrm{C}$ in an atmosphere of $5 \% \mathrm{CO}_{2}$.

\section{Assay controls}

Medium control (medium without cells), Negative control (medium with cells but without the experimental drug/compound) and Positive control (medium with cells and with 50uM of CPT (Camptothecin)/75uM of $\mathrm{H}_{2} \mathrm{O}_{2}$ ).

\section{ANTI-HAV ASSAY OF ETHANOLIC EXTRACT OF WHOLE PLANT OF T.CORDIFOLIA ON HUH-7 CELLS BY MTT ASSAY [11-13]}

Seed $200 \mu \mathrm{l}$ cell suspension in a 96 -well plate at required cell density (20,000 cells per well), without the selected plant extarct. Allow the cells to grow for about 12 hours. Then, add appropriate concentrations of the selected plant extract $(3.125 \mu \mathrm{g} / \mathrm{mL}, 6.25 \mu \mathrm{g} / \mathrm{mL}, 12.5 \mu \mathrm{g} / \mathrm{mL}, 25 \mu \mathrm{g} / \mathrm{mL}$ and 50 $\mu \mathrm{g} / \mathrm{mL})$. Incubate the plate for $24 \mathrm{hrs}$ at $37^{\circ} \mathrm{C}$ in a $5 \% \mathrm{CO} 2$ atmosphere. After the incubation period, takeout the plates from incubator, and remove spent media and add MTT reagent to a final concentration of $0.5 \mathrm{mg} / \mathrm{mL}$ of total volume. Wrap the plate with aluminium foil to avoid exposure to light. Return the plates to the incubator and incubate for 3 hours. Remove the MTT reagent and then add $100 \mu \mathrm{l}$ of solubilisation solution (DMSO). Gentle stirring in a gyratory shaker will enhance dissolution. Occasionally, pipetting up and down may be required to completely dissolve the MTT formazan crystals especially in dense cultures. Read the absorbance on a spectrophotometer or an ELISA reader at $570 \mathrm{~nm}$ and $630 \mathrm{~nm}$ used as reference wavelength.

The IC50 value was determined by using linear regression equation i.e. $\mathrm{Y}=\mathrm{Mx}+\mathrm{C}$. Here, $\mathrm{Y}=50, \mathrm{M}$ and $\mathrm{C}$ values were derived from the viability graph.

Cell viability was obtained using the following equation:

Percent cell viability $=\frac{\text { Test } 570 \mathrm{~nm}-620 \mathrm{~nm}}{\text { Control } 570 \mathrm{~nm}-620 \mathrm{~nm}} \times 100$

\section{RESUltS AND DiscuSSION}

In the present study, ethanolic extract of whole plant of Tinospora cordifolia was tested for antiviral activity against HAV. For antiviral screening against Hepatitis A virus, toxicological effect of selected plant extract was determined through MTT cell proliferation assay. The standard used in this assay was Camptothecin (CPT) at $25 \mu \mathrm{G}$ concentration. Plant extract was tested at $3.125 \mu \mathrm{g} / \mathrm{mL}$, $6.25 \mu \mathrm{g} / \mathrm{mL}, 12.5 \mu \mathrm{g} / \mathrm{mL}, \quad 25 \mu \mathrm{g} / \mathrm{mL}$ and $50 \mu \mathrm{g} / \mathrm{mL}$ concentrations. The percent cell viability of standard drug was found to be $43.01 \%$ and plant extracts at $3.125 \mu \mathrm{g} / \mathrm{mL}$, $6.25 \mu \mathrm{g} / \mathrm{mL}, 12.5 \mu \mathrm{g} / \mathrm{mL}, \quad 25 \mu \mathrm{g} / \mathrm{mL}$ and $50 \mu \mathrm{g} / \mathrm{mL}$ concentrations were found to be $97.90 \%, 93.66 \%, 81.29 \%$, $62.58 \%, 56.24 \%$ respectively (table 2 , figure 2 ). The cell morphology was observed and recorded under microscope (figures 3-4). The results clearly indicated the selected plant extract shows a dose dependent activity and it was maximum at $50 \mu \mathrm{g} / \mathrm{mL}$ concentration where it shows only $56.24 \%$ of virus viability and it was comparable to standard drug where it shows $43.01 \%$ of viability.

Herbal medicines are free from side effects, adverse effects and they are economical and easily available will be beneficial for the mankind over the centuries [1]. Hepatitis A is a viral liver disease that can 
cause mild to severe illness. HAV is transmitted through ingestion of contaminated food and water or through direct contact with an infectious person. Almost everyone recovers fully from Hepatitis A with a lifelong immunity. The risk of Hepatitis A infection is associated with a lack of safe water, and poor sanitation and hygiene (such as dirty hands). Epidemics can be explosive and cause substantial economic loss. A safe and effective vaccine is available to prevent Hepatitis A. Safe water supply, food safety, improved sanitation; hand washing and the Hepatitis A vaccine are the most effective ways to combat the disease.

In May 2016, The World Health Assembly adopted the first "Global Health Sector Strategy on Viral Hepatitis, 2016-2021". The strategy has a vision of eliminating viral hepatitis as a public health problem and this is encapsulated in the global targets of reducing new viral hepatitis infections by $90 \%$ and reducing deaths due to viral hepatitis by $65 \%$ by 2030 . WHO also organizes World Hepatitis Day on 28 July every year to increase awareness and understanding of viral hepatitis.

The current treatment of care has significant side effects. Hence, there is a need to develop anti-HAV agents from plant origin, which are less toxic, more efficacious and cost-effective. Previous studies demonstrated that medicinal plants used for centuries against different diseases including viral diseases and become a focal point to identify, isolate and purify new compounds to treat diseases. Many traditional medicinal plants and herbs were reported to have strong antiviral activity like Glycyrrhiza uralensis (Licorice root) [14]. Phytochemical screening of selected plant extract reveals (table 2) the presence of different secondary metabolites like alkaloids, flavonoides, tannins, resins, steroids. Presence of these compounds in alone or combination may be responsible for the observed antiviral activity of $T$. cordifolia.

\section{CONCLUSION AND FUTURE SCOPE}

By the above experimentation, we have conclude that the ethanolic extract of whole plant of T.cordifolia shows a dose dependent anti-HAV activity and it was maximum at 50 $\mu \mathrm{g} / \mathrm{mL}$ concentration with $56.24 \%$ of virus viability and it was comparable to standard drug Camptothecin where it shows $43.01 \%$ of viability. Presence of alkaloids, flavonoides, tannins, resins and steroids in selected plant extract in alone or in combination might be responsible for the observed antiviral activity of $T$. cordifolia. Further studies need to be carried out to isolate the individual compounds from the crude ethanolic extract, their purification, characterization and pharmacological screening will be an informative tool in revolutionizing the plant based medicine for treatment of viral infections.

\section{Figures and Tables}

All figures in the manuscript should be numbered sequentially using Arabic numerals (e.g., Figure 1, Figure 2), and each figure should have a descriptive title. The figure number and title should be typed in italic type, single-spaced, and centered across the bottom of the figure, in 9-point Times New Roman, as shown below.

Tables should be numbered sequentially using Arabic numerals (e.g., Table 1, Table 2), and each table should have a descriptive title. The table number and title should be typed in normal type, single-spaced, and centered across the top of the table, in 8-point Times New Roman, as shown below.
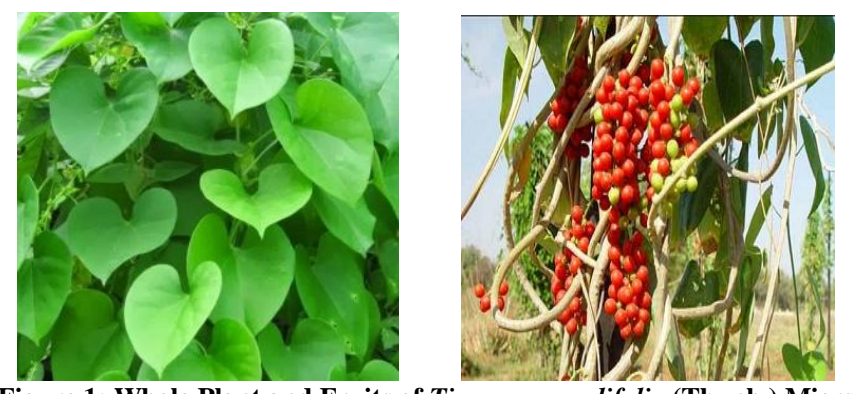

Figure 1: Whole Plant and Fruits of Tinospora cordifolia (Thunb.) Miers

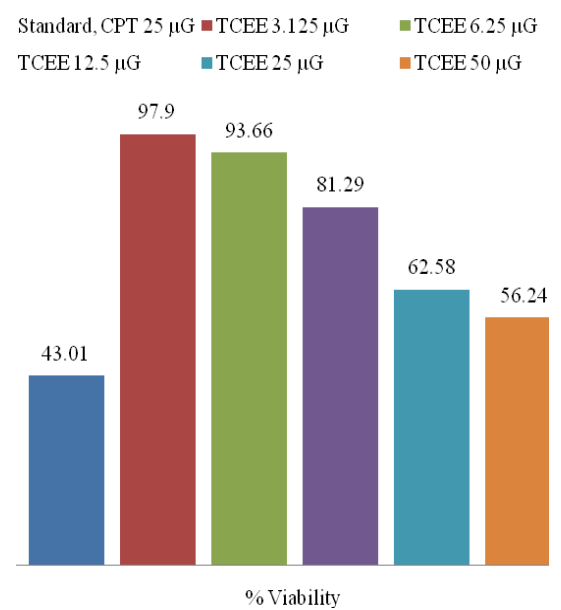

TCEE: Tinospora cordifolia ethanolic extract; CPT: Camptothecin

Figure 2: Anti-Viral activity of whole plant of T. cordifolia Ethanolic Extract (TCEE)

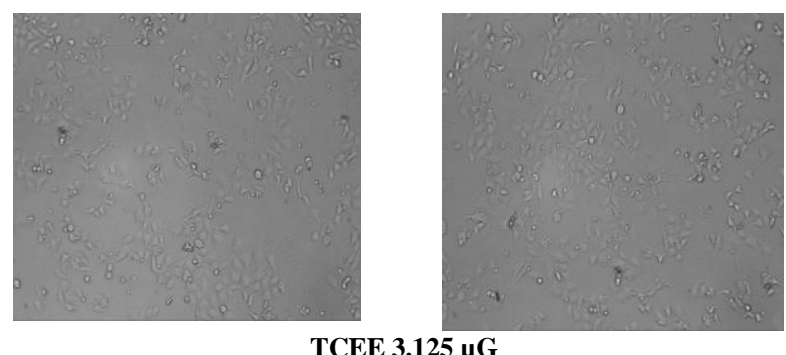



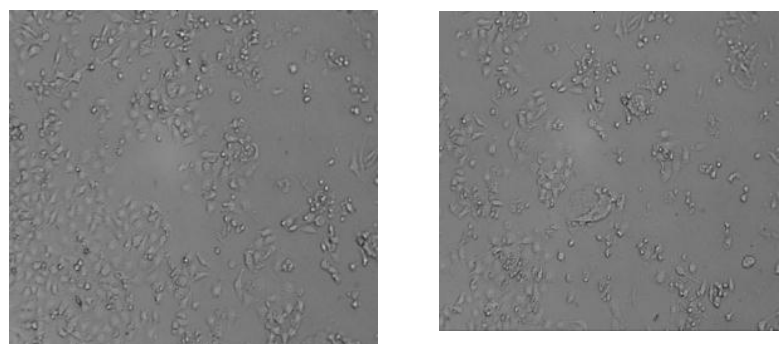

TCEE $6.25 \mu \mathrm{G}$

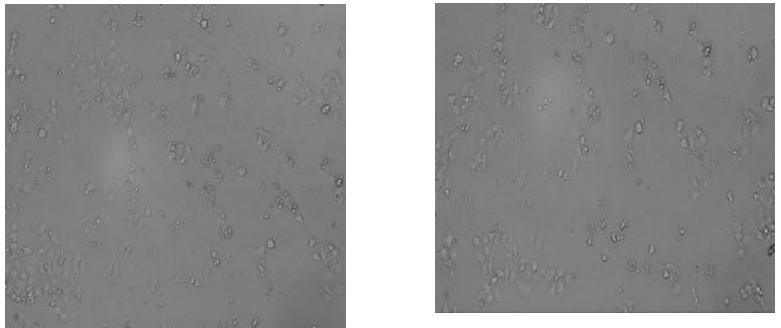

TCEE $12.5 \mu \mathrm{G}$

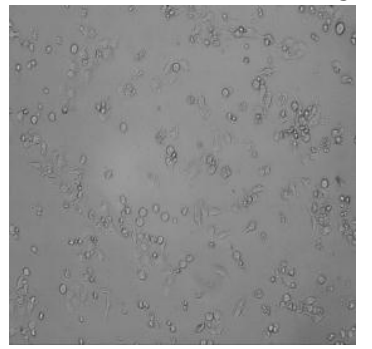

TCEE $25 \mu \mathrm{G}$

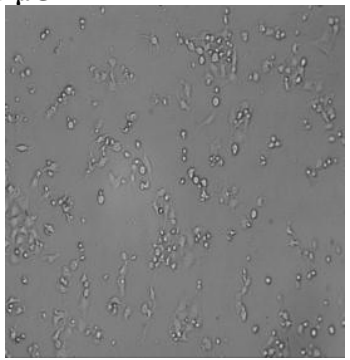

Figure 3: Photomicrographs of morphology of Huh-7cells cells

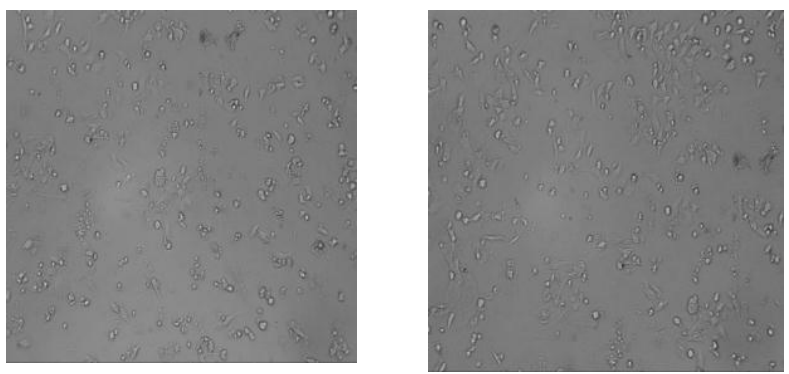

TCEE $50 \mu \mathrm{G}$

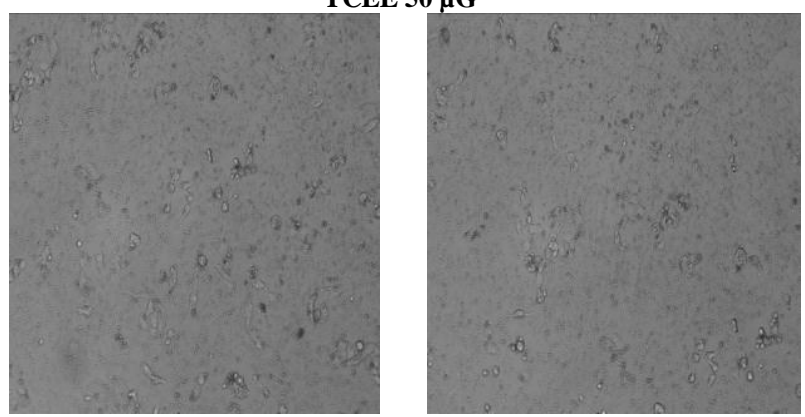

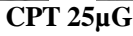

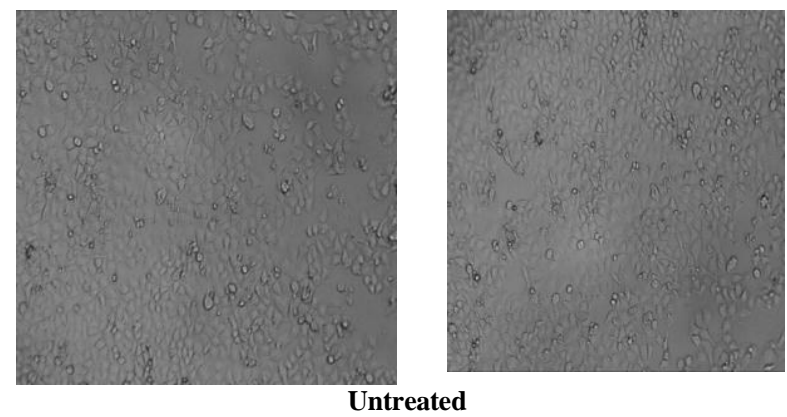

Figure-4: Photomicrographs of morphology of Huh-7cells cells

TABLE 1: PRELIMINARY PHYTOCHEMICAL ANALYSIS OF ETHANOLIC EXTRACT OF WHOLE PLANT OF TINOSPORA CORDIFOLIA

\begin{tabular}{|c|l|c|}
\hline S. No. & \multicolumn{1}{|c|}{ Secondary metabolite } & Ethanolic Extract \\
\hline 1. & Tannins & - \\
\hline 2. & Alkaloids & + \\
\hline 3. & Saponins & + \\
\hline 4. & Phenols & + \\
\hline 5. & Flavonoids & + \\
\hline 6. & Glycosides & + \\
\hline 7. & Carbohydrates & + \\
\hline 8. & Steroids \&Triterpenoids & + \\
\hline 9. & Proteins \& amino acids & '+'Present, '-' Absent \\
\hline
\end{tabular}

Table 2: Anti-Viral activity of Tinospora cordifolia Ethanolic Extract (TCEE)

\begin{tabular}{|c|c|c|c|c|c|c|c|c|}
\hline & Blank & Untreated & $\begin{array}{l}\text { CPT } \\
25 \mu \mathrm{G}\end{array}$ & $\begin{array}{l}\text { TCEE } \\
3.125 \\
\mu \mathrm{G}\end{array}$ & $\begin{array}{l}\text { TCEE } \\
6.25 \\
\mu G\end{array}$ & $\begin{array}{l}\text { TCEE } \\
12.5 \\
\mu \mathrm{G}\end{array}$ & $\begin{array}{l}\text { TCEE } \\
25 \mu \mathrm{G}\end{array}$ & $\begin{array}{l}\text { TCEE } \\
50 \mu G\end{array}$ \\
\hline Reading 1 & 0.013 & 0.822 & 0.356 & 0.81 & 0.762 & 0.666 & 0.539 & 0.477 \\
\hline Reading 2 & 0.015 & 0.831 & 0.371 & 0.809 & 0.788 & 0.683 & 0.506 & 0.465 \\
\hline Mean & 0.014 & 0.8265 & 0.3635 & 0.8095 & 0.775 & 0.6745 & 0.5225 & 0.471 \\
\hline $\begin{array}{l}\text { Mean OD- } \\
\text { Mean Blank }\end{array}$ & & 0.8125 & 0.3495 & 0.7955 & 0.761 & 0.6605 & 0.5085 & 0.457 \\
\hline $\begin{array}{l}\text { Standard } \\
\text { Deviation }\end{array}$ & & 0.0063 & 0.0106 & 0.0007 & 0.0183 & 0.0120 & 0.0233 & 0.0084 \\
\hline $\begin{array}{l}\text { Standard } \\
\text { Error }\end{array}$ & & 0.0045 & 0.0075 & 0.0005 & 0.0130 & 0.0085 & 0.0165 & 0.0060 \\
\hline Viability \% & & 100 & 43.01 & 97.90 & 93.66 & 81.29 & 62.58 & 56.24 \\
\hline
\end{tabular}

\section{REFERENCES}

[1] M. Ramaiah, K. Devilal,, S. Babu and P. Harika, "In-vitro MABA anti-tuberculosis assay of Eclipta Alba(L.) Hassk whole plant", The Pharma Innovation Journal, Vol. 6, Issue 5, pp.103-105, 2017.

[2] R. Maddi, C. Guntupalli, Y. Kanuri, "In vitro biological standardization, formulation and evaluation of directly compressed polyherbal anthelmintic tablets" Pharmacognosy Journal, Vol. 5, Issue 3, pp.130-134, 2013.

[3] M.J.M. Christenhusz, and J.W.Byng, "The number of known plants species in the world and its annual increase" Phytotaxa, Vol. 261, Issue 3, pp. 201-217, 2016.

[4] S. Saha and S. Ghosh, "Tinospora cordifolia: One plant, many roles" Ancient Science of Life, Vol. 31, Issue 4, pp: 151-159, 2012.

[5] Kirti S, Mishra NP, Singh J and Khanuja SPS. Tinospora cordifolia (Guduchi), a reservoir plant for therapeutic 
applications: A Review. Indian Journal of Traditional Knowledge 2004, 3(3):257-270.

[6] K.R. Khandelwal, "Practical Pharmacognosy techniques and experiments", Nirali Prakashan publications, India, $8^{\text {th }}$ ed. 2001.

[7] K.R. Brain, T.D. Terner, "The practical evaluation of Phytopharmaceuticals", Wright Scientechnica, Bristol, pp. 435,1975

[8] World Health Organization Expert Committee. Quality Control Methods for Medicinal Plant Materials, WHO press publishes, Geneva, 2002.

[9] J.B. Harborne, "Phytochemical methods - A guide to modern techniques of plant analysis", Chapman \& Hall publications, $3^{\text {rd }}$ ed. 1998.

[10] C.K. Kokatae, "Practical Pharmacognosy", Vallabha Prakashan publications, India New Delhi, pp.107-103, 2002.

[11] T. Javed et al, "In-vitro antiviral activity of Solanum nigrum against Hepatitis C Virus", Virology Journal, Vol. 19, Issue 8, pp. 26, 2011.

[12] S. Rehman et al, "Antiviral activity of Acacia nilotica against Hepatitis C Virus in liver infected cells”, Virology Journal, Vol. 8, pp. 220, 2011.

[13] N.C. Priya and P. Saravana Kumari, "Antiviral activities and cytotoxicity assay of seed extracts of Piper longum and Piper nigrum on Human Cell Lines", International Journal of Pharmaceutical Sciences Review and Research, Vol.44, Issue 1, pp. 197-202, 2017.

[14] J. Wang et al, "Glycyrrhizic acid as the antiviral component of Glycyrrhiza uralensis Fisch. against coxsackievirus A16 and enterovirus 71 of hand foot and mouth disease", Journal of Ethnopharmacology, Vol. 147, Issue 1, pp.114-121,2013.

\section{AUTHOR PROFILE}

Dr. Ramaiah Maddi pursed M. Pharm., and Ph.D., in Pharmaceutical Sciences from Andhra University, Visakhapatnam, A.P., India in 2009 \& 2014. He is currently working as Associate Professor and HOD in Department of Pharmacognosy, Hindu College of Pharmacy, Guntur, A.P., India. He is a member of The International Natural Product Sciences Taskforce (INPST) society, Poland, Life member of Association of Pharmaceutical Teachers of India (APTI), and Association of Pharmacy Professionals (APP), India. He has published more than 50 research papers in reputed international journals including Thomson Reuters and written 2 text books of pharmacy. He has 9 years of teaching and research experience. 